\title{
Phonological Errors in Reading Tawasul among Cirangrang Society, Bandung District
}

\author{
Lina Marlina \\ Universitas Islam Negeri (UIN) Sunan Gunung Djati Bandung \\ linamarlina@uinsgd.ac.id
}

\begin{abstract}
This study aims to describe and analyze the form of phonological errors in reading tawasul and their causes, then formulate solutions to these errors so as to minimize errors and be able to read tawasul well, perfectly, and in accordance with the rules. This research is a qualitative descriptive study with an analytical approach to errors in reading tawasul. The data in this study were obtained by free listening, recording, and writing techniques. They were done sequentially with several resource persons who became leaders in each activity that contained the reading of tawasul in it. From the results of observations, several errors were found in the form of addition, subtraction, and substitution of letters, tasydid, and mad signs. Additionally, some spelling errors were also found due to similarities in pronunciation, such as the letter 2 becomes 1 , letter

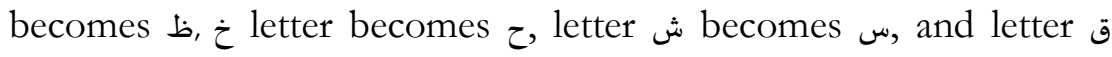
becomes 5 .
\end{abstract}

Keywords: Phonological; error analysis; reading tawasul

\begin{abstract}
Abstrak
Penelitian ini bertujuan untuk mendeskripsikan dan menganalisis bentuk kesalahan fonologi dalam membaca tawasul dan penyebabnya, kemudian merumuskan solusi dari kesalahan tersebut sehingga dapat meminimalisir kesalahan dan mampu membaca tawasul dengan baik, sempurna, dan sesuai kaidah. Penelitian ini merupakan penelitian deskriptif kualitatif dengan pendekatan analitik terhadap kesalahan dalam membaca tawasul. Data dalam penelitian ini diperoleh dengan teknik mendengarkan, merekam, dan menulis bebas. Dilakukan secara berurutan dengan beberapa nara sumber yang menjadi pimpinan dalam setiap kegiatan yang memuat bacaan tawasul di dalamnya. Dari hasil observasi ditemukan beberapa kesalahan berupa penambahan, pengurangan, dan
\end{abstract}


penggantian huruf, tasydid, dan mad. Selain itu, beberapa kesalahan ejaan juga ditemukan karena kesamaan pengucapan, seperti huruf $\varepsilon$ menjadi أ ض ض huruf menjadi س dan huruf a menjadi ك.

Kata kunci: Fonologis; analisis kesalahan; tawasul

\section{Introduction}

Many people are fascinated by the sound of Arabic both in the words of poetry, as well as the chanting of the holy verses of the Qur'an. A German writer named Sigrid Hunke said, "How can anyone resist the beauty of this language, its sound logic and unparalleled charm? The neighbors of the Arabs themselves in countries then conquered have fallen for the charm of that language" 1 .

Like other languages, Arabic also has a branch of linguistics that discusses the sound of language which is called Ashwat, or better known as Phonology. Phonology discusses the function of sound that comes out of a clear arrangement in terms of its specifications, nature, and intended function or the science that discusses the study of sound in words and sentence structure in a language from another language ${ }^{2}$.

Phonology is also a branch of linguistics that discusses the sounds of language to distinguish the meaning of a word ${ }^{3}$.

Aswat is of vital importance in Arabic as it can influence other linguistic sciences. Basically, every science is complex and interrelated with each other, either directly or indirectly. Unfortunately, nowadays it is very rare for people to study Ashwat even though it is useful in keeping the tongue when reading various Arabic texts, such as prayer, dhikr, and tawasul. More importantly, if there are holy verses of the Qur'an in it, it is certainly obligatory to apply the rules of reading the Qur'an, known as the study of Tajweed, and Ashwat is closely related to Tajweed. It is even mentioned in a journal that Ashwat was born from the adaptation of Tajweed or the study of correct ways of reading the Qur'an ${ }^{4}$. In short, the Arab community began to recognize the science of sound after the revelation of the Qur'an. However, we will not discuss further the

${ }^{1}$ Mukhlis Lubis, 'Analisis Kesalahan Berbahasa Arab Dalam Pembelajaran Hukum Islam', Ibya Al-Arabiyah: Jurnal Pendidikan Babasa Dan Sastra Arab 5, no. 2 (2019): 334-39.

${ }^{2} \mathrm{C}$ James, 'Exploring Error Analysis: Errors in Language Learning and Use' (London: Longman, 1998).

${ }^{3}$ Lina Marlina, 'Pengantar Ilmu Ashwat' (Fajar Media, 2019).

${ }^{4}$ Muhammad Nur Sholihin, 'Peran Ilmu Al-Ashwat Dalam Pelafalan Huruf Hijaiyah (KajianTeoritik Linguistik Terapan)', SALIHA: Jurnal Pendidikan \& Agama Islam 3, no. 2 (2020): $110-27$. 
connection between Ashwat and Tajweed. We will discuss Arabic readings/texts, namely tawasul which contains ways to get closer to Allah SWT. It is interesting to study since the rules of reading it are often ignored as it is not the holy Qur'an ${ }^{5}$.

Tawasul is often found in many events as a form of gratitude to Allah SWT, or at a regular recitation held on Friday nights, which is better known among the Ahlu Sunnah Wal Jamaah, especially among the Nahdiyyin community. Tawasul is one method of achievement to be able to easily get closer to Allah SWT' ${ }^{6}$. In the reading of tawasul, there are ways (wasilah) to get closer to Allah SWT, through the prophets and auliya, as well as pious people who are close to Allah SWT, and those of His lovers, even though they had died. It is because, in essence, the "dead" is only for the bodies, while their spirits are still alive.

The reading of tawasul, which in fact is in Arabic, is often inappropriate and not in accordance with the rules of reading Arabic which are summarized in Ashwat. Our society tends to assume that only reading Qur'an should fulfill the reading rules. Thus, it is often found in society many readings of tawasul that are phonologically wrong, such as replacing, adding, or subtracting. Whereas according to Andriani ${ }^{7}$, apart from being an international language, Arabic, especially in Mecca which is a meeting place for millions of people from every part of the world, becomes their language of communication. Arabic also acts as the language of ubudiyah communication in the form of dhikr and prayer which includes tawasul.

In this sense, the change in the reading of Arabic words or sentences will affect their meaning. It can be seen in the pronunciation changes between the wضرة which means 'present', and the word حظرة which means 'prohibiting', 'cursing' which has a bad connotation. This clearly must be corrected as it can affect the intention, in which the communication with Allah SWT is expected to be established by these words or sentences. Although Allah SW'T is Omniscient of what is meant by His servant, even with the wrong pronunciation such as in prayer, however, the shari'a in this prayer should be obeyed in order to achieve maqbul prayers. Likewise, when we read tawasul by being accommodated by the

${ }^{5}$ Ilma Dzina Setyowati, Erlina Sulistiyawati, and Gema Rifa Cahyaningrum, 'Analisis Kesalahan Berbahasa Tataran Fonologi Dalam Laporan Hasil Observasi Siswa', Jurnal Bindo Sastra 3, no. 1 (2019): 1-13.

${ }^{6}$ Faisal Muhammad Nur, 'Konsep Tawassul Dalam Islam', Substantia: Jurnal Ilmu-Imu Usbuluddin 13, no. 2 (2011): 267-73.

7 Asna Andriani, 'Urgensi Pembelajaran Bahasa Arab Dalam Pendidikan Islam', Ta'allum: Jurnal Pendidikan Islam 3, no. 1 (2015): 39-56. 
prophet, auliya, and pious people with correct language rules, it is hoped that our prayers, intentions, and desires can be accepted by Allah SWT ${ }^{8}$.

Thus, our focus in this research is to identify the phonological errors that exist in the reading of tawasul and to describe these errors, either adding, removing, subtracting, or replacing letters when pronounced in a tabular form. Then, the causal factors can be found, and it is expected that the solutions to those problems can be generated.

This research entitled Phonological Errors in Tawasul Reading among the Cirangrang Community is a qualitative descriptive study with an analytical approach to errors in reading tawasul. Meanwhile, the research design that we used in this study was a content analysis design, because the data we got were in the form of readings by several tawasul leaders in the Cirangrang community.

The data were obtained through observation technique. This technique was carried out by means of free listening and conversation. The activities were carried out by listening then recording every phonological error in the reading of tawasul by using a recording application on the cellphone, so that when the research was finished, we could listen to it again to strengthen and select certain phonemes with the same errors and the highest occurrence.

The benefit of this research is to find out the phonological errors found in the reading of tawassul among the Cirangrang people, so that this research is able to reduce the errors that exist in each reading.

As for previous research that has been done by other researchers, it is about phonological errors in reading Arabic texts, so it can be concluded that the reading of tawasul can also be analyzed in terms of errors therein.

The participants in this study were tawasul leaders in the Cirangrang community and were used to leading tawasul in every event. Then the ones chosen were not arbitrary, but purposefully by taking participants from 3 age groups: 1) Teenagers (age 19 years), 2) Adults (ages 25+) and, Elderly/Seniors (ages $50+$ )..

\section{Result and Discussion}

Mistakes are common things that often occur in human's live. Arabic proverb says:

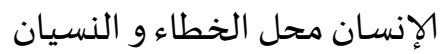

Humans are where mistakes and forgetfulness lie.

${ }^{8}$ Fitria Lathifah, Syihabuddin Syihabuddin, and M Zaka Al Farisi, 'Analisis Kesalahan Fonologis Dalam Keterampilan Membaca Teks Bahasa Arab’, Arabiyat: Jurnal Pendidikan Bahasa Arab Dan Kebahasaaraban 4, no. 2 (2017): 174-84. 
However, it does not mean that humans keep making mistakes and forgetting, even doing it on purpose. Since mistakes are not the reasons to keep doing wrong things, humans must learn from mistakes and make mistakes the lessons to prevent them from doing the same things. Moreover, humans should be able to turn mistakes into works or to create a powerful solution. As it is said that the best people who make mistakes are those who admit their mistakes and correct their mistakes so that they do not regret due to such mistakes later on. Prophet Muhammad PBUH said:

$$
\text { كل بني آدم خطاء وخير الخطائين التوابون }
$$

Every child of Adam's descendants has made mistakes and the best of those who do wrong is the one who repents of his iniquity. (HR At-Tirmidhi No. 2499) $)^{9}$.

In his book entitled "Common Errors in Language Learning", George argues that language errors are the use of unwanted speech forms, especially a form of speech that is not desired by programmers and language teaching teachers ${ }^{10}$.

Unwanted speech forms are speech forms that deviate from standard language rules.

The objects of error are certainly diverse, including errors in language. Language errors are deviations from the norm in an utterance as a result of the influence of the first language ${ }^{11}$. Coorder ${ }^{12}$ classifies language errors in three terms.

1. Mistake is an error that occurs normally and consciously, and language speakers know and correct it.

2. Error is an error that occurs due to the speaker's lack of focus, negligence, and inaccuracy.

3. Slip, is an error that can be corrected directly by the speaker, but without feedback from other speakers.

4. In learning a foreign language, these mistakes will often occur naturally. Moreover, this happens to people who have never studied a foreign language thoroughly, thus it is bound to happen. However, among students,

${ }_{9}^{9}$ Nurkholis Nurkholis, 'Analisis Kesalahan Berbahasa Dalam Bahasa Arab', Al-Fatbin: Jurnal Bahasa Dan Sastra Arab 1, no. 01 (2018): 10-21.

${ }^{10} \mathrm{H}$ Victor George, 'Common Errors in Language Learning: Insights from English.', 1972.

${ }^{11}$ Jack C Richards, 'Second Language Acquisition: Error Analysis', Annual Review of Applied Linguistics 1 (1980): 91-107. Press, 1981).

${ }^{12}$ S P Coorder, 'The Significant of Learner's Errors' (Oxford: Oxford Univerversity 
mistakes like this are natural because this is a process which is not short and cannot be avoided.

According to Abduh Ar Rajihi, error analysis is a continuation of contrastive analysis. This analysis is more focused on errors that occur in native speakers and non-native speakers. For native speakers, mispronunciation is impossible unless it is due to physiological factors, such as illness or psychological factors, such as speech disorders. While the errors that exist in non-native speakers occur due to several factors in learning and because of their ignorance of the language system at several levels, such as morphology, syntax, and semantics or in phonology ${ }^{13}$. This phonological analysis observes errors in language in terms of sound or speech.

Arabic has a distinctive sound that is not shared by other languages, it is long vowels and doubling in terms of consonants ${ }^{14}$. In addition, the Arabic language also has other characteristics, it has sounds that are similar and close together. This resemblance is clearly a problem for Arabic learners and people who read Arabic texts such as prayer, remembrance, and tawasul. Sound and pronunciation errors are also influenced by the diversity of regional languages in Indonesia, such as the pronunciation of the letter $\varepsilon$ to "nga" in Javanese society $^{15}$. The results of the observations show that there are several errors in the form of lengthening words that should not be extended and there were phrases whose pronunciation was almost the same.

1. Letter $\varepsilon$ becomes $i$

2. Letter ض becomes

3. Letter $\tau$ becomes $\tau$

4. Letter ش ش

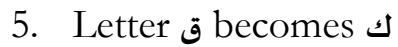

There are also other errors in the form of addition, subtraction, or substitution. They are presented in the form of a table as shown below.

\section{Error Identification}

Table of phonological errors in the reading of tawasul among the people of Cirangrang

13 Abduh Al-Rajihi, 'Ilm Lughah Al-Tathbiqi Wa Ta'lim al-'Arabiyah', Iskandariah: Dar al-Ma'rifah al-Jami'iyah, 1995.

${ }^{14}$ Muhammad Afif Amrulloh and Haliyatul Hasanah, 'Analisis Kesalahan Fonologis Membaca Teks Bahasa Arab Siswa Madrasah Tsanawiyah Lampung Selatan', Arabiyatuna: Jurnal Babasa Arab 3, no. 2 (2019): 209-28.

15 Khasanah Khasanah and Muhammad Nanang Qosim, 'Wacana Sosiofonologis Pelafalan Huruf/ع/Dalam Huruf Hijaiyah Pada Masyarakat Jawa', URECOL, 2017, 323-32. 


\begin{tabular}{|c|c|c|}
\hline $\begin{array}{c}\text { Incorrect } \\
\text { Pronunciation }\end{array}$ & $\begin{array}{c}\text { Correct } \\
\text { Pronunciation }\end{array}$ & Error Identification \\
\hline حَظَردةٍ & حَضْرَةٍة & ظ ض ض bubstituting \\
\hline آَلَنَّبِى & آَلنَّبِّ & Omitting ي tasydid (doble consonants) \\
\hline سَيَّدِنْ & سَتِيَدِنَا & $\begin{array}{l}\text { Omitting mad (long vowels) and } \\
\text { substituting it by ن }\end{array}$ \\
\hline 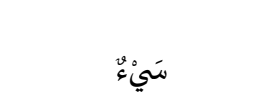 & 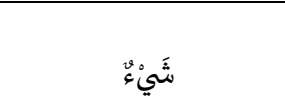 & س ش ش Substituting \\
\hline أَسْنَحَابِهِ & أَصْحَحَابِهِ & س ص ص Substituting \\
\hline آَلْمَنَيَكَةُ & 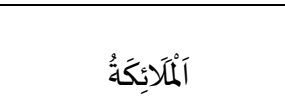 & Omitting $\mid$ mad \\
\hline كَلْيْنَ & كُلِّ & ن ن Adding mad and \\
\hline بَقِيَِةٍ & بَقِقِيَةٍ & Omitting stasydid \\
\hline أَنْبِيَ؛ & أَنْبِيَاءٍ & Omitting I mad \\
\hline 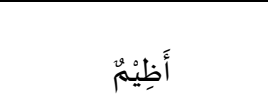 & 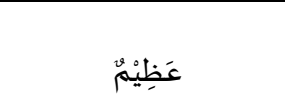 & Substituting ع by \\
\hline 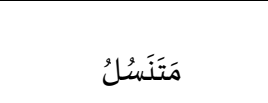 & مَاتَتَاسُلُ & Omitting two 1 mad \\
\hline خُصُصًَا & خُصُوْصًَا & Deleting, mad \\
\hline أَخِنَّا & أَخَيْنَا & Omitting ي and adding $\dot{\tau}$ tasydid \\
\hline
\end{tabular}




\begin{tabular}{|c|c|c|}
\hline أَرْوَاِِيْ & أَرْوَاحِ & Adding ي mad \\
\hline آَلْكَرَابَةِة & آَألقَرَابَةِة & Substituting ق by \\
\hline
\end{tabular}

\section{Addition Errors}

In the practice of reading tawasul among the people of Cirangrang, there are additions in the form of letters, tasydid, or mad (increasing the length of the reading). This is much influenced by the tone or song they usually use so that what should be short becomes long. In contrast, the reading which should be long becomes short, as in the following example.

\begin{tabular}{|c|c|c|}
\hline أَرَوَاحَحْ & أَرْوَاحَ & Adding mad \\
\hline
\end{tabular}

Meanwhile, the addition of tasydid and letters occurred because they did not see the actual book and usually listened to the leader of tawasul. The possible wrong reading by the leader then becomes a hereditary legacy. This is illustrated in the following table.

\begin{tabular}{|c|c|c|}
\hline كَلِّينَن & 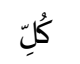 & ن Adding mad and \\
\hline أَخِنَنَا & أَخَيْنَا & $\begin{array}{l}\text { Omitting ي and } \\
\text { adding } \dot{\tau} \text { tasydid }\end{array}$ \\
\hline
\end{tabular}

\section{Omission Errors}

In addition to adding letters, tasydid, or mad, in the reading of tawasul among the people of Cirangrang, there are also many omissions, both in letters, tasydid and mad. However, most people tend to eliminate mad in which words that should be long are read short and vice versa. This is influenced by how fast the readers read tawasul that makes it difficult to control the length of a word, as in the following example.

\begin{tabular}{|l|l|l|}
\hline مَاتَنَاسُُلُ & $\begin{array}{l}\text { Omitting } \\
\text { two I mad }\end{array}$ \\
\hline خَتَسُشُنُ & $\begin{array}{l}\text { Deleting } \\
\text { g mad }\end{array}$ \\
\hline
\end{tabular}




\begin{tabular}{|l|l|l|}
\hline خُصُصُوْصًا & $\begin{array}{l}\text { Deleting } \\
\text { وُصُصًا }\end{array}$ & mad \\
\hline
\end{tabular}

The cause of omission of letters or tasydid is the same as in addition because of the forgetting factor and the mistakes made have been hereditary. Moreover, omission errors often occur due to the difficulty of pronouncing certain letters, especially the letters with bold pronunciation and adding tasydid thus it is rather difficult, as in the following example.

\begin{tabular}{|l|l|l|}
\hline & بَقِقيَيَّةٍ & $\begin{array}{l}\text { Omitting } \\
\text { يَasydid }\end{array}$ \\
\hline
\end{tabular}

\section{Substitution Errors}

This is the most dominant case. In this study, we found several substitution errors, especially the substitution of letters due to the similarity in the pronunciation of certain letters whose makhraj is the same, but there are certain characteristics that make them different. However, due to lack of understanding, people tend to generalize it. In addition, this error is also influenced by the tongue of the Indonesian people, such as the letter kaf or qaf which when pronounced, will tend to pronounce the letter $k$, as in the following example.

\begin{tabular}{|c|c|c|}
\hline حَظُرٍَة & حَضْرَةٍ & ظ اض Substituting \\
\hline آَلْكَرَابَةِة & اَلْقَرَابَةِة & Substituting ق ق Syy \\
\hline
\end{tabular}

We found that the impact of substitution errors on meaning would be greater than that of adding or subtracting mad. We also found many articulations in the pronunciation of sounds, such as in the pronunciation of 'ain and bamzah which Indonesian people find it easier to pronounce with clear articulation of the letter a or hamzah because in Indonesian many words use the vowel "a", while in 'ain it is rarely used, except by the Javanese, but the pronunciation becomes nga as in the sentence عالمين becomes ngaalamiin. It is the same as this word.

\begin{tabular}{|l|l|l|}
\hline عَظظطيْمُ & Substituting عby i \\
\hline
\end{tabular}




\section{The Causes of Phonological Errors in Tawasul Reading Among Cirangrang Community}

From the results of the research we have conducted through observation technique involving several leaders of tawasul in 3 age groups and the collection of data obtained by free listening techniques, recording techniques, and writing techniques, we found several causes of phonological errors in the reading of tawasul among the Cirangrang people that we studied which will be divided into two parts.

\section{General causes (Ghalib)}

This cause occurs in all circles and often occurs in society.

a. Distinguishing between Arabic in the Qur'an and Arabic texts other than the Qur'an. This is a very basic reason because when we tried to ask one of the leaders of tawasul about this, he explained that the laws of reading other than the Qur'an are not punished like the Qur'an, or in other words the law of reading the Qur'an. The Qur'an does not apply to Arabic texts other than the Qur'an. We do agree with this, but with a note that we are not allowed to replace, add, and subtract letters, tasydid, or mad that are not in place. Thus, what should be read in length remains long, regardless of the length of the vowel, it depends on our estimation. However, when it contains the reading of the Qur'an, we still have to obey the laws of reading that are in the Qur'an, because this will clearly affect the meaning. Likewise, readings with short characters must still be read short. Arabic is the language of communication with Allah SWT., which certainly requires us to improve the reading on tawasul because it will affect the clarity of what we convey to Allah Swt. This improvement is expected to be one of the strong reasons for the acceptance of our prayers and intentions contained in the tawasul.

b. Lack of interest in reading the tawasul that they have memorized. The feeling of "already memorized" brings people not to look back at the correct and appropriate reading, because they think, what they have memorized is what is appropriate. The crisis of repeating readings that have been memorized or muraja'ah, is a problem in our society. This may be due to limited time or their busyness in various affairs, that they do not have time to just sit down and read again solemnly, full of high concentration.

c. The influence of the mother tongue or first language. This often happens not only in society, but also among language learners and teachers. What we found from the community was the habit of people pronouncing 'ain with $a$ because in Indonesian there are many words built with the vowel "a", and it influences the reading of Arabic texts, one of which is tawasul.

d. Limited study and facilities to learn Arabic letters, starting from how they are pronounced, where they come out, their characteristics, the thickness, 
the length, and so on. Even if there is a place for learning, usually in the Cirangrang community this is combined with learning interpretations (tafsir) or short lectures by preachers because people think that religious advice is more important in the post-marriage period, while studying that are complex in nature are the business of young people and those who specifically study it.

e. Prioritizing reading tones that sound good and make it easier and relax in reading tawasul. This cause is slightly more dominant than the others. We found this in words that should be short, but are read long and vice versa, which should be read long and then read short because they follow the flow of the tune. There are also those who just add to their solemnity by reading in fragments in one particular place with loud voice (zahir), while in other places low voice (sirr). When it is found in a zabir place, there is usually a reading that should be read short, but instead is read long.

f. Fast reading so that it is difficult to control, whether the letters, tasydid, or mad.

g. There are several letters whose pronunciation and place of articulation are similar, so that people, especially those who do not understand the actual form of reading, read them similarly.

\section{Specific Causes (Khaashshun)}

These factors only occur in certain circles. They are:

a. The increasing age factor causes the energy and stability of the speech organs to decrease so that the readings that come out of the place are less clear and inappropriate. This is the reason why we divided the participants of tawasul readers into three age groups as previously discussed.

b. The habit of not bringing books or reading texts because they already know and feel they have mastered them. Some people do not want to bring reading texts because they only rely on rote memorization of tawasul leaders. Thus, if the tawasul leaders misread or forget some parts then replace, add, or subtract them, then the community also makes mistakes.

\section{Solutions to Overcome the Phonological Errors in Tawasul Reading}

A correct tawasul reading will basically clarify our intentions, intentions, or prayers, because errors that occur in pronunciation will also result in errors in meaning. The purpose of this research is to identify errors in reading tawasul and then produce solutions, so that in subsequent readings, the same mistakes or new mistakes can be avoided. In this case, we try to formulate solutions for phonological errors in the reading of tawasul among the people of Cirangrang.

1. Repeating the rote of tawasul and correct the wrong reading. As a 
preventive measure, the participants are expected to bring the reading text or book so that even the slightest mistake can be avoided.

2. Conducting studies to examine how to read and pronounce the Arabic text correctly, that includes its makhraj, its nature, and so on, so that there will be no repeated or hereditary errors.

3. Improving the competence of tawasul reading for tawasul leaders because they are the spearhead of the participants (mustami) or congregation in measuring the accuracy of reading pronunciation. This of course requires cooperation from units that specifically study language from a phonological point of view or units that study the correct and appropriate reading of the Qur'an. This unit can consist of tawasul leaders in the community or stakeholders who take care of community and community affairs.

\section{Conclusion}

In this study, several errors occurred in the reading of tawasul in words, phrases, and sentences. We also found some errors in the pronunciation of letters due to similarities in terms of pronunciation, and also the addition, subtraction, and substitution of letters, tasydid, and mad in the reading. We also conclude some general and specific causes, they are:

1. Distinguishing between Arabic in the Qur'an and Arabic texts other than the Qur'an.

2. Lack of interest in reading the already memorized tawasul.

3. The influence of the mother tongue or first language.

4. Limited study or facilities to learn Arabic letters.

5. Prioritizing reading tones that sound good and make it easier and relax in reading tawasul.

6. Fast reading that make it difficult to control, whether letters, tasydid or mad.

7. There are several letters whose pronunciation and place of articulation are similar or almost the same.

8. Age factor.

9. The habit of not bringing books or reading texts because they feel they already mastered it.

Among the phonological errors in the reading of tawasul are as follows:

1. the reading of the word عظيم changes to أظيم

2. الكرابة to reading the word القرابة

After knowing the cause of these errors, we also provide several solutions.

1. Repeating the rote of tawasul and correcting the wrong reading.

2. Conducting studies to examine how to read and pronounce the Arabic text correctly.

3. Improving the competence of tawasul reading for tawasul leaders. 


\section{Bibliography}

al-Rajihi, Abduh. 'Ilm Lughah Al-Tathbiqi Wa Ta'lim al-'Arabiyah'. Iskandariah: Dar al-Ma'rifah al-Jami'iyah, 1995.

Amrulloh, Muhammad Afif, and Haliyatul Hasanah. 'Analisis Kesalahan Fonologis Membaca Teks Bahasa Arab Siswa Madrasah Tsanawiyah Lampung Selatan'. Arabiyatuna: Jurnal Bahasa Arab 3, no. 2 (2019): 209_ 28.

Andriani, Asna. 'Urgensi Pembelajaran Bahasa Arab Dalam Pendidikan Islam'. Ta'allum: Jurnal Pendidikan Islam 3, no. 1 (2015): 39-56.

Coorder, S P. 'The Significant of Learner's Errors'. Oxford: Oxford Univerversity Press, 1981.

George, H Victor. 'Common Errors in Language Learning: Insights from English.', 1972.

James, C. 'Exploring Error Analysis: Errors in Language Learning and Use'. London: Longman, 1998.

Khasanah, Khasanah, and Muhammad Nanang Qosim. 'Wacana Sosiofonologis Pelafalan Huruf/ع/Dalam Huruf Hijaiyah Pada Masyarakat Jawa'. URECOL, 2017, 323-32.

Lathifah, Fitria, Syihabuddin Syihabuddin, and M Zaka Al Farisi. 'Analisis Kesalahan Fonologis Dalam Keterampilan Membaca Teks Bahasa Arab’. Arabiyat: Jurnal Pendidikan Bahasa Arab Dan Kebahasaaraban 4, no. 2 (2017): 174-84.

Lubis, Mukhlis. 'Analisis Kesalahan Berbahasa Arab Dalam Pembelajaran Hukum Islam'. Ibya Al-Arabiyah: Jurnal Pendidikan Bahasa Dan Sastra Arab 5, no. 2 (2019): 334-39.

Marlina, Lina. 'Pengantar Ilmu Ashwat'. Fajar Media, 2019.

Nur, Faisal Muhammad. 'Konsep Tawassul Dalam Islam'. Substantia: Jurnal IlmuIlmu Ushuluddin 13, no. 2 (2011): 267-73.

Nurkholis, Nurkholis. 'Analisis Kesalahan Berbahasa Dalam Bahasa Arab'. AlFathin: Jurnal Bahasa Dan Sastra Arab 1, no. 01 (2018): 10-21.

Richards, Jack C. 'Second Language Acquisition: Error Analysis'. Annual Review of Applied Linguistics 1 (1980): 91-107.

Setyowati, Ilma Dzina, Erlina Sulistiyawati, and Gema Rifa Cahyaningrum. 'Analisis Kesalahan Berbahasa Tataran Fonologi Dalam Laporan Hasil Observasi Siswa'. Jurnal Bindo Sastra 3, no. 1 (2019): 1-13. 
248 | Arabiyatuna : Jurnal Bahasa Arab, Vol. 5, No. 2, 2021

Sholihin, Muhammad Nur. 'Peran Ilmu Al-Ashwat Dalam Pelafalan Huruf Hijaiyah (KajianTeoritik Linguistik Terapan)'. SALIHA: Jurnal Pendidikan \& Agama Islam 3, no. 2 (2020): 110-27. 